\title{
ILMU KOLONIAL DI MALAYSIA: PERSPEKTIF MAQASID SYARIAH
}

\author{
Ahmad Farid Abdul Jalal, Rahimin Affandi Abd. Rahim, Ab. Halim Ismail, \\ Huzaimah Ismail \& Muhammad Ikhlas Rosele
}

Akademi Pengajian Islam, Universiti Malaya, Kuala Lumpur

faqir_ila_rabbih@um.edu.my

\begin{abstract}
:
As a country that once colonized by the British, Malaya indeed vulnerable to the influence of British ideology. This occurs through a mechanism of colonial knowledge developed by British to learn and dominate the Malay community. As a result of colonial influence can be traced in all aspects of Malay community life. The findings of this research show that the colonial have their own policies and approach when it comes to the issue of Islam in the Malay community. They try to kill the potential of Islam and replace it with world-view and British paradigm then embed it into the community. The results of the Maqasid analysis on the legacy of colonial knowledge still prove too much effort to consolidate Islam should be done by Islamic scholars. Islamic scholars have to reject and correct negative outlook placed on Islam.

Keywords: Colonial knowledge, Islamic studies, Post colonialism, World-view.
\end{abstract}

\section{Pendahuluan}

Sejarah manusia, selain bergantung kepada takdir Allah, merupakan reaksi dan respon manusia terhadap persekitarannya. Ia didasarkan kepada ilmu dan ketakwaan kepada Allah, samada umat manusia mematuhi hukum Allah ataupun sebaliknya. Untuk menghadapi permasalahan ini manusia memang dibekalkan dengan alat untuk penyelesaian masalah; akal dan wahyu Allah.

Sejarah telah menyaksikan Malaysia dilanda dengan penjajahan akibat kelemahan diri umat Islam sendiri. Kita dijajah selama 500 tahun, suatu tempoh masa yang agak lama yang menyebabkan kesan penjajahan ini berakar umbi dengan begitu mendalam. Sayugia dimaklumi bahawa selepas proses kemerdekaan diperolihi, kebanyakan negara bekas tanah jajahan barat telah memberi respon mencabar dan berusaha menghakis warisan penjajah. Ia 
membabitkan kawasan Indo-Pakistan, Amerika Selatan, Afrika dan Asia. Usaha penghakisan ini walaupun bermula dengan usaha politik, tetapi ianya menekankan sentuhan pemikiran dan ilmu, bagi menjadikannya lebih kukuh dan kekal lama. Berasaskan kepada latar belakang ini, kajian ini akan cuba mengupas respon Islam terhadap warisan tinggalan penjajahan, ilmu kolonial.

\section{Pendekatan Kajian}

Kajian ini menggunakan pendekatan pasca kolonialisme dalam bentuk rekonstruksi yang disesuaikan dengan konsep maqasid syariah. Pendekatan ini antaranya;

1. Pendekatan Subelturn studies yang mendedahkan sejarah daripada golongan bawahan yang tertindas. Mereka memainkan peranan utama dalam perjalanan sejarah tetapi peranan mereka dilupakan kerana penulisan sejarah biasanya penuh dengan agenda kolonial dan feudal. ${ }^{1}$

2. Pendekatan pasca kolonialism yang mencabar dan merekonstruksi ilmu dan sejarah yang ditulis oleh golongan kolonial. ${ }^{2}$ Sebaliknya sejarah daripada pandangan golongan terjajah akan didedahkan. Ia termasuk usaha merekonstruksi kesemua keilmuan yang dihasilkan oleh pihak kolonial barat. Secara terang-terangan pengaruh world-view sekular kolonial telah diterapkan dalam keilmuan ini, samada ilmu sains sosial $^{3}$ ataupun ilmu sains tulen. ${ }^{4}$

3. Pendekatan epistemologi-occidentalism Islam. Ia mendedahkan kelemahan pendekatan kolonial-orientalism yang dipakai oleh sarjana barat. Sebagai gantinya, pendekatan ini menggunakan world-view Islam yang lebih holistik, bukannya secara tempelan semata-mata yang biasanya dilakukan oleh golongan sosialisme. ${ }^{5}$ Pendekatan epistemologi Islam ini yang

1 Mohamad Saleeh Rahamad (2007), Oksidentalisme Dalam Persuratan : Juzuk Penting Dalam Kajian Pascakolonial, Pemikir.

2 Zawiah Yahya (1994), Resisting Colonialist Discourse, Penerbit UKM.

3 Mohd Hazim Shah Abdul Murad (2005), " Epistemology Colonial : Satu Analisis Cirri Dan Kesannya “, Dalam (Edit) Mohamad Daud Mohamad, Pascakolonialisme Dalam Pemikiran Melayu, DBP : Kuala Lumpur, h. 91-92

${ }^{4}$ Mohd Hazim Shah (2007), Historicizing Rationality : The Transmission Of Rationality And Science To The Malay States Under British Rule, dalam Asian Journal Of Social Science, 35, h. 216-241.

5 Shamsul Amri Baharuddin (2004), "Oksidentalisme: Pengertian Dan Hala Tuju", Dalam Jurnal Pemikir, h. 1-19 
diusahakan oleh S.M.Naqiub al-Attas akan ditokok tambah dengan ilmu Maqasid Syariah. Kita perlu melakukan analisis falsafah ilmu barat yang mengandungi elemen ontologi (apa yang wujud), epistemologi (isu asal usul, dasar, metode dan batas ilmu) dan aksiologi (sistem nilai) terhadap pandangan world-view dan kognitif barat berasaskan world-view Islam. Usaha ini secara langsung memerlukan pemakaian pemikiran meta-kognitif dan usaha re-definition terhadap semua konsep yang dihasilkan oleh sistem kognitif Barat. ${ }^{6}$ Mengikut Syed Naquid al-Attas, kita perlu memberikan definasi kita sendiri tentang ajaran Islam tanpa perlu bergantung dengan apa yang diberikan oleh orientalis barat. ${ }^{7} \mathrm{Hal}$ ini ditegaskan kerana kita mempunyai world-view kita tersendiri tentang agama Islam yang berasaskan kepada sumber wahyu dan akal terpimpin. ${ }^{8}$ Secara induktifnya, kita boleh memahami bahawa program Islamisasi ilmu pengetahuan yang diusulkan oleh Syed Naquid al-Attas dan Ismail Faruqi merupakan gagasan intelektual untuk menyaingi genre orientalisme barat. Lagipun, golongan orientalis lebih merupakan outsider yang mengkaji dan memandang Islam dengan kaca mata yang sarat dengan bias sekularisme dan kepentingan barat. $^{\text {? }}$

\section{Pendekatan Maqasid: Satu Pengenalan}

Pendekatan maqasid ini diperkenalkan oleh Mahmood Zuhdi Abdul Majid. Ia berasaskan amalan fuqaha Islam silam yang mengkaji sesuatu perkara, ilmu dan falsafah berdasarkan semangat maqasid untuk memastikan kesesuaian ataupun tidak dengan Islam. Selain daripada ada Sahabat-fuqaha zaman Rasulullah mengambil pendekatan literal, memang terdapat Sahabat yang menggunakan pendekatan Maqasid dalam memahami dan mengamalkan ajaran

6 Mohd Azhar Abd Hamid (2001), Pengenalan Pemikiran Kritis Dan Kreatif, Skudai: Penerbit Universiti Teknologi Malaysia, hh. 98-116.

7 Syed Muhammad Naquidd Al-Attas (1979), Aim And Objective of Islamic Education, Jeddah: University Of King, h.1; Abdul Aziz(2003), Islam And Secularism. Kuala Lumpur: ISTAC, hh. 123-124.

8 Syed Muhammad Naquidd Al-Attas (1980), The Concept Of Education In Islam: A Framework For An Philosophy Of Education. Kuala Lumpur: Angkatan Belia Islam Malaysia, h. 43.

9 Syed Muhammad Naquidd Al-Attas (2003), Islam And Secularism, hh. 162-163; Ismail Faruqi (1995), Islamization Of Knowledge, Herndon: IIIT, h. 35. 
Islam. Kedua pendekatan ini mendapat pengesahan daripada Rasulullah sendiri. Antara lainnya penilaian Maqasid ini akan mengambilkira samada wujud ataupun tidak prinsip-prinsip Islam dalam sesuatu objek yang dikaji. Antara prinsip-prinsip ini adalah tauhid, rasionalistik, tiga tingkatan maslahah (Daruri, Hajiyi dan Tahsini) wasatiyah, World Affirmative, budaya ilmu dan societal. Ia menuntut pengkaji maqasid ini berfikir secara strategik, futuristik dan holistik dalam mengkaji sesuatu perkara. ${ }^{10}$

Ia perlu dibezakan dengan pendekatan Islam liberal yang juga mendakwa menggunakan pendekatan maqasid dalam kajian mereka. Kelemahan pendekatan maqasid golongan liberalis dapat dilihat daripada beberapa aspek.

1. Ia tidak dibuat kerana kepentingan Islam sejati, tetapi hanya sebagai alasan dan topeng untuk mendapat pulangan keduniaan sementara. Contohnya, terdapat beberapa LSM di Indonesia seperti Jaringan Islam Liberal yang sering menggunakan hujah maqasid demi untuk mendapatkan dana asing yang mempromosikan idealism demokrasi liberal barat. Begitu juga halnya dengan NGO atas nama Islam di Malaysia. Mereka menggunakan dana asing (Yayasan Konrad Adenauer) turut sama menyokong tuntutan IFC yang dibawa oleh oleh Majlis Perundingan Malaysia bagi Ajaran Buddha, Kristian, Hindu dan Sikh (MCCBCHS). Mereka memang menyedari usaha menyokong kewujudan masyarakat yang plural- demokratik di Malaysia; akan menjemput sokongan dan dokongan dana asing yang melimpah ruah. $\mathrm{Hal}$ ini sanggup dilakukan walaupun ianya akan menjejaskan kuasa Ketuanan Melayu Islam di Malaysia. ${ }^{11}$

2. Ia menjadikan world-view sekularisme (aspek ontologi, epistemologi dan aksiologi) yang bersifat anti agama sebagai asas berfikir untuk sesuatu perkara. Hal ini dibuat kerana bagi mereka world-view barat adalah model pemikiran terbaik yang diperlukan untuk zaman moden ini. Hasilnya,

10 Zainal Abidin ( 2003), Sosiosophologi: Sosiologi Islam Berbasis Hikmah. Bandung: Penerbit Pustaka Setia, hh. 59-67; Kuntowijoyo (2004), Islam Sebagai Ilmu: Epistemology, Metodologi Dan Etika, Jakarta: Teraju Mizan, hh. 4-9

11 Ummu Atiyah Ahmad Zakuan (2007), Hak Asasi Manusia Dan Demokrasi Dari Persepktif Islam Dan Barat, Dalam Mohd Izani Mohd Zain (ed.), Demokrasi Dan Dunia Islam : Perspektif Teori Dan Praktik, Kuala Lumpur : Penerbit UM, h. 106-112; Anis Shakila Binti Ismail (2006), Pemikiran Islam Liberal Di Malaysia : Kajian Terhadap Isu Yang Ditimbulkan Oleh Farish Noor Dan Syed Akhbar Ali. Kertas projek Sarjana Muda Usuluddin .APIUM, h. 43 
mereka akan mengkritik habis-habisan formula fuqaha Islam silam dan menjustikasikan semua formula barat menggunakan konsep maqasid Syariah. ${ }^{12}$ Dalam soal ini kita boleh menerimapakai pandangan Profesor Muhammad Syukri Salleh yang mengkritik kaedah pembasmian kemiskinan di barat yang menggunakan teori dan formula barat moden, tanpa menyedari bahawa formula barat itu memang berasaskan kepada falsafah sekularisme. ${ }^{13}$

\section{Pembahasan}

\section{Pendekatan Pembangunan Ilmu Kolonial: Satu Analisis}

Ilmu kolonial adalah ilmu yang mengumpulkan serba serbi maklumat tentang masyarakat tanah jajahan bagi tujuan pengawalan dan pemantauan yang sepatutnya. Ia berasaskan dasar dan epsitemologi (falsafah, pendekatan, metodologi dan tafsiran) yang dilakukan oleh sarjana penjajah colonial British terhadap masyarakat Tanah jajahan. Tujuannya untuk menguasai aspek politik dan pemikiran masyarakat Tanah jajahan. Ia adalah sinonim dengan disiplin orientalism, iaitu ilmu yang mengkaji ruang fizikal dan abstrak/pemikiran masyarakat bukan barat. Orientalis ialah sekelompok ilmuan mengkaji Islam dari sudut pandang mereka. Mereka mengkaji 'Timur' secara budaya bahkan ideologi, sebagai suatu bentuk wacana dengan dokongan institusi, kosa kata, keilmuan, imajinasi, doktrin, bahkan birokrasi kolonial dan gaya kolonial. ${ }^{14}$ Mereka mendakwa kajian itu dilakukan demi nilai ilmiah murni tanpa ada maksud dan tujuan yang lain. Namun begitu, pandangan metodologi orientalis mengandung pelbagai bentuk konfrontasi terhadap kebudayaan tertentu. Ia dikonstruk khusus untuk membezakan antara kedua masyarakat tadi tanpa mengambikkira persetujuan masyarakat timur.

Menurut Abid al-Jabiri, dalam pendekatan orientalis ada dua aspek yang perlu dikaji. Pertama, aspek yang berkaitan dengan hubungan antara orientalis dan imperialisme. Biasanya, hal ini kelihatannya tersembunyi, khususnya dengan konflik antara Islam dan Kristian pada abad pertengahan. Hasilnya

\footnotetext{
12 Abd Moqsith Ghazali (2007), Mengubah Wajah Fiqh Islam, dalam Abd Hakim dan Yudi Latif (eds.), Bayang-Bayang Fanatisme: Esai-Esai Untuk. Mengenang Nurcholish Madjid, Jakarta: PSIK (Universitas Paramadina), h. 412-431.

${ }^{13}$ Muhammad Syukri Salleh (2009), "Melayu-Islam Dan Sumber Kekuatan Yang Diabaikan", dalam Kalthum Ibrahim(ed.), Dunia Melayu Dan Islam : Satu Wacana. Bangi: Penerbit Universiti Kebangsaan Malaysia, hh. 3-26.

${ }^{14}$ Edward W Said (1985), Orientalism, Middlesex: penguin Books, h. 2.
} 
daripada paparan konflik ini, mereka merendah-rendahkan pemikiran Islam. Hal ini agak jelas apabila pemikiran umat Islam dikatakan sebagai pemikiran bangsa Semit yang dianggap sangat mundur. ${ }^{15}$ Kedua, aspek yang berkaitan dengan situasi objektif, pensejarahan dan metodologi yang diaplikasikan oleh orientalis. Pada masa orientalisme muncul, begitu pula pemikiran Eropah mengenal gerakan intelektual yang bertujuan melakukan reviewing (ulang kaji) sejarah kebudayaan Eropah. Dengan tersusunnya sejarah kebudayaan Eropah ini, mereka mendakwa tentang keuniversalan metodologi sejarah Eropah ini dan menganggap sejarah lain tidak mempunyai peranan yang signifikan.

Proses pembangunan ilmu kolonial di kawasan Tanah Jajahan seperti Tanah Melayu memang menjadi polisi utama yang ditetapkan kuasa penjajah British di Britain. Di Britain, pada masa itu, projek Enlightmen dan Renaisance (program menghidupkan falsafah positivisme - sekularisme) sedang giat berjalan dan falsafah ini diterima oleh kerajaan Britain dalam dasar negara. ${ }^{16}$ Pejabat Tanah Jajahan di London telah menetapkan dasar agar ilmu colonial diwujudkan bagi memastikan penjajahan dapat bertahan lama. Untuk itu, mereka memerlukan korpus ilmu khusus untuk menjayakan program ini. Atas dasar itu mereka memerlukan pakar-pakar orientalis untuk membangun ilmu kolonial ini. Pakar ini akan memberikan panduan bagaimana ilmu kolonial boleh dibangunkan. Pihak pusat perlu menerima pakai cadangan yang diberikan oleh pakar-pakar orientalis ini ${ }^{17}$. Antara mekanisme pembentukan sarjana-pentadbir kolonial;

1. Memilih kader tertentu yang mampu menguasai bahasa dan budaya masyarakat tanah jajahan. Mereka perlu diterapkan dengan falsafah EuroCentric dan memandang rendah bangsa bukan barat. Mereka dilarang mengambil sikap bersimpati dengan masyarakat tanah jajahan. ${ }^{18}$

\footnotetext{
15 Ibid, h. 75.

16 Samuel Wee Tien Wang (1991), British Strategic Interests In The Straits Of Malacca 17861819, Tesis Sarjana Untuk Simon Fraser University.

17 Kees Groeneboer (1999), Politik Bahasa Kolonial Di Asia, Wacana, v. 1, no 2, h. 201-220.

18 Sivachandralingam Sundara Raja (2015), The Early British Administrators In The Malay States, 1874-1909, Jurnal Sejarah, v. 23, no 1,h. 32-39.
} 
2. IPT di barat (British dan Belanda) ditugaskan melatih kader-kader ini tentang sejarah, bahasa, budaya dan ilmu philologi bagi menjalankan misi mendapatkan maklumat tentang masyarakat tanah jajahan. ${ }^{19}$

3. Calon yang terpilih ini perlu menjalankan misi mendapatkan sebanyak mungkin maklumat tentang masyarakat Tanah Jajahan untuk tujuan pentadbiran masyarakat. Contohnya, hal ini memang telah dikumpulkan oleh sejarahwan Portugis, ${ }^{20}$ Belanda $^{21}$ dan British. ${ }^{22}$

4. Selain daripada kader ini bertugas di tanah jajahan, mereka diwajibkan menjalankan usaha pengumpulan data melalui beberapa langkah; ${ }^{23}$

a. Menguasai bahasa pribumi untuk membolehkan proses komunikasi dan menjalankan program law and order di dalam masyarakat.

b. Menjalankan survey ataupun kajian tinjauan bagi mengumpulkan maklumat mengenai kehidupan sosial, alam sekitar dan segala perkara yang berkait dengan masyarakat pribumi.

c. Mengumpul maklumat statistikal melalui kaedah banci yang kemudiannya dikategorikan mengikut pembahagian yang khusus.

d. Menyimpan pelbagai bahan dan artifak yang dikutip dari survey and banci untuk dipamerkan kepada kalangan yang berminat.

e. Mengasaskan suatu sistem pengintipan dan perisikan yang dianggap perlu bagi menjamin keselamatan dan kestabilan politik pemerintahan kolonial

f. Membina suatu perpustakaan bistorigrafi yang dicopkan sebagai hak milik pribumi yang kemudiannya dijadikan sebagai bahan utama pengajaran kepada masyarakat.

g. Melakukan proses kajian philology terhadap koleksi historigrafi milik orang Melayu yang kemudiannya diterbitkan dalam pelbagai bentuk penerbitan ilmiah untuk tujuan rujukan pentadbir dan akademik.

19 Sudibyo (2007), Kembali Ke Filologi : Filologi Indonesia Dan Tradisi Orientalisme, Humaniora, v. 19, h. 107-118.

20 Boxer, C.R. (1965), Some Portuguese Sources For Indonesian Historiography, Dalam Soedjatmoko (Eds), An Introduction To Indonesian Historiography, New Haven : Cornell University Press.

${ }^{21}$ Ibid

22 Barlow, H.S.(1995), Swettenham, Kuala Lumpur : Southdene Bhd, h. 1-31.

23 Shamsul Amri Baharuddin (1983), " Perancangan Pembangunan Negara Selepas Merdeka 1957-1975 : Tinjauan Sejarah Perkembangan Sosio-Ekonomi Malaysia”, Dalam Malaysia : Sejarah Dan Proses Pembangunan, Kuala Lumpur, h. 337-339. 
5. Semua bahan mentah yang terkumpul ini dianalisa dan dijadikan sebagai asas untuk memahami dan menguasai masyarakat tanah jajahan. Terpenting lagi, banyak dasar British di Tanah Melayu dibuat berasaskan dapatan kajian daripada bahan mentah ini.

Secara ringkasnya, ilmu kolonial ini yang memang terkumpul dalam bentuk karya, laporan, data dan historiografi tentang masyarakat tanah jajahan Melayu Islam di perpustakaan di Barat. Ia sering dijadikan rujukan asas bagi setiap kajian yang membabitkan masyarakat Melayu Islam di Alam Melayu. Lebih penting lagi, ilmu kolonial ini dalam bentuk dasar, teori dan pemikiran (epistemologi) masih lagi diterima pakai secara meluas di dalam dasar dan IPTA di Malaysia walaupun kemerdekaan telah diperolihi.

\section{Analisa Maqasid terhadap Ilmu Kolonial Di Malaysia}

Hasil analisa, didapati beberapa ulasan khusus membabitkan ilmu kolonial di Malaysia. Antaranya;

\section{Keperluan Mendesak Untuk Melakukan Proses Reviewing Hegomoni Ilmu Kolonial Di Malaysia.}

Usaha penolakan dan penghapusan warisan ilmu kolonial merupakan maslaha Daruri dan bukannya setakat Tabsiniah. Andainya usaha ini tidak dilakukan sudah pasti keburukan akan terus terkena kepada Islam. Lagipun, berbanding dengan agama lain, Islam sering dianggap sebagai musuh abadi (Evil Empire $)^{24}$ oleh sarjana kolonial barat. Ia didasarkan kepada beberapa sebab;

1. Fakta dan teori yang dibawa oleh ilmu kolonial akan terus merosakkan citra Islam (maslaha daruri) memandangkan teori-teori tajaan kolonial ini telah establish di dalam jurnal terujuk dan ensklopedia antarabangsa yang dianggap sebagai kononnya bersifat objektif (dihasilkan secara adil tanpa apa-apa kepentingan). Ia bakal dan memang telah dijadikan rujukan baku bagi pengkaji yang ingin mengetahui realiti masyarakat Islam di Tanah Melayu. Contohnya M.B. Hooker seorang tokoh ternama dalam bidang undang-undang Islam di Asia Tenggara yang sering dijadikan rujukan telah menganggap sarjana Melayu silam tidak lebih sebagai penterjemah yang baik dan tidak memberikan apa-apa sumbangan bermakna. Ia

${ }^{24}$ Fawaz A. Gerges (1999), America And Political Islam; Clash Of Cultures Or Clash Of Interest, Cambridge : Cambridge University Press, h. 21-28. 
mengemukakan pandangan ini berasaskan rekord kolonial British di Alam Melayu. ${ }^{25}$

2. Teori songsang tentang Islam masih lagi secara hegomoninya dipakai oleh golongan sekular di Malaysia. Dalam soal ini, para sarjana telah membezakan konsep dominasi (penguasaan secara kekerasan) dengan hegomoni (penguasaan sesuatu perkara yang mendapat legitimasi kerana didokong oleh tokoh politik yang sah). Contohnya di Malaysia semasa, usaha menolak tafsiran perlembagaan Malaysia mengikut perspektif sekular telah mendapat tentangan hebat daripada pelbagai NGO. Ini kerana sejak merdeka perlembagaan Malaysia sentiasa ditafsirkan oleh para hakim dan pengamal undang-undang mengikut perspektif barat, memandangkan mereka lahir daripada sistem pendidikan British. Hal ini amat malang sekali kerana walaupun Malaysia telahpun merdeka tetapi nilai-nilai warisan kolonial masih lagi cuba dikekalkan. ${ }^{26}$ Atas dasar itu, kita perlu memberikan sentuhan ilmu dengan menerang alasan ilmiah kenapa ilmu kolonial berserta dengan semua semangatnya yang berasaskan kepentingan kolonial perlu direview untuk ditolak.

3. Teori salah tentang Islam diburukkan lagi dengan fenomena Islamophobia yang dilakukan oleh media barat. ${ }^{27}$ Terkini hal ini semakin mendesak dengan munculnya elemen ekstrimism Islam. Ia bakal membenarkan dakwaan barat bahawa Islam adalah agama perkauman yang membenarkan penindasan dilakukan pada golongan bukan Islam. Hal ini memang ada asasnya dalam sejarah Tanah Melayu. Mengikut rekord kolonial, Perjuangan Dato Bahaman dikaitkan dengan gerakan keganasan melawan kuasa British yang kononnya berusaha mentamadunkan Tanah Melayu. ${ }^{28}$ Lebih khusus

${ }^{25}$ M.B. Hooker (1983), “ The Translation Of Islam Into South-East Asia “, dalam Islam In South-East Asia, Leiden, h. 9-11

26 Rahimin Affandi Abdul Rahim, Nor Adina Abdul Kadir ( 2012). Gerakan Feminisme Liberalism Di Malaysia : Analisis Kritikal, dalam prosiding World Congress On Islamic Systems 1- 5 December 2012. Kota Bharu, Kelantan

${ }^{27}$ Rahimin Affandi Abd Rahim (2010), "Pemodenan Dan Kesejahteraan Manusia Dari Perspektif Orientalism", dalam Seminar Serantau Islam dan Kesejabteraan Sejagat, Fakulti Usuluddin, UNISSA, Brunei, pada 24-25 Februari 2010

${ }^{28}$ Lukmanul Hakim Darusman (2008). Jihad In Two Faces Of Shariah: Sufism And Islamic Jurisprudence (Fiqh) And The Revival Of Islamic Movements In The Malay World. Tesis Ph.D yang tidak diterbitkan, The Australian National University. 
lagi, perjuangan Dato Bahaman ini dikaitkan juga dengan Islam kerana beliau dilaporkan mendapat sokongan daripada Tokku Paloh. ${ }^{29}$

\section{Mengajar Kita Memahami Falsafah Sebenar Yang Mendasari Ilmu Kolonial.}

Sesuai dengan semangat maqasid yang menuntut kita berfikiran strategik dan futuristik, kita akan mendapati pembinaan ilmu kolonial ini berasaskan beberapa falsafah; Pertama, falsafah kolonialisme dan evolutionism. Falsafah ini menganggap kuasa British sebagai penyelamat (saviour) masyarakat Melayu ${ }^{30}$ daripada kejahilan diri sendiri. Falsafah evolutionism yang berasaskan teori evolusi Darwin menganggap tamadun barat sebagai lebih tinggi dan agung, berbanding dengan keadaan masyarakat timur. ${ }^{31}$ Pencapaian tamadun barat yang membanggakan ini kononnya disebabkan kerana penerimaan fahaman sekularisme yang menolak kepentingan agama di dalam hidup manusia. ${ }^{32}$ Sebaliknya, masyarakat selain barat yang masih berpegang kepada agama telah dianggap sebagai mundur, bodoh, bebal dan tidak bertamadun yang harus ditamadunkan oleh masyarakat Eropah, melalui proses penjajahan. ${ }^{33}$ Bahkan kononnya tugas menjajah demi untuk mengajar masyarakat timur ini telah dianggap sebagai tanggungjawab sosial yang terpaksa dimainkan oleh masyarakat Eropah. ${ }^{34}$

Berdasarkan kepada hal ini, ianya dapat mendorong kebanyakan sarjana barat yang mengkaji terhadap undang-undang adat Melayu memburuk-

${ }^{29}$ Muhammad Ikhlas Rosele, Rahimin Affandi Abd Rahim \& Mohd Anuar Ramli (2015). Islamisasi Awal di Pahang: Satu Tinjauan Teori. Jurnal Kemanusiaan, 24(1).

${ }^{30}$ Dalam soal ini Winstedt menegaskan : Though his very name has been forgotten at Kuala Kangsar, Captain James Low was the saviour of Perak.. and along with the name of Low, Perak ought to enscribe in the letters of gold the name Robert Fullerton, Governor of Prince of Wales Island, Singapore and Malacca. Lihat R.O. Winstedt (1934), " A History of Perak ", dalam JMBRAS, 12 (1), h. 73.

${ }^{31}$ Edward Said (1981), Covering Islam, How The Media And The Experts Determine Hows We See The Rest OfThe World, London, h. 39-40, 60 dan 62.

32 Zainal Kling (1994), Antropologi tafsiran : sumbangan kebudayaan Melayu kepada teori, Syarahan perdana untuk pengukuhan profesor, Kuala Lumpur, h. 12-13.

33 Sebagai contohnya Frank Swettenham menyatakan bagaimana Raja Muda Abdullah telah meminta kuasa British untuk campurtangan di Negeri Perak dengan tujuan : to teach bim how to rule this unruly country, but the circumstances alone made that interference the duty of the paramount power. Lihat F. Swettenham (1893), About Perak, Singapore, h. 5 dan 9. 34 Wang Gungwu (1970), Scholarship and the history and politics of Southeast Asia, Flinders University of South Australia, h. 11. 
burukkan undang-undang Islam yang dianggap sebagai ketinggalan zaman, zalim, tidak berperikemanusiaan ${ }^{35}$ dan banyak lagi bentuk keburukan yang dinisbahkan kepada syariah Islam. ${ }^{36}$ Begitu juga semua sifat buruk yang dipunyai oleh orang Melayu dikatakan berpunca dari pengamalan mereka terhadap ajaran Islam, seperti suka berserah kepada takdir, tidak menghargai masa, ${ }^{37}$ menolak pemodenan ${ }^{38}$ dan sebagainya yang perlu diubah dengan memperkenalkan cara hidup barat, termasuklah sistem undang-undang Eropah. ${ }^{39}$

Kedua, teori Diffusionisme yang menganggap kemajuan masyarakat Melayu bukan kerana sifat asal diri mereka yang baik dan proaktif terhadap sesuatu kemajuan, ${ }^{40}$ tetapi kerana faktor pengaruh budaya asing (difusi budaya) yang secara langsung telah ditiru oleh masyarakat Melayu. Sikap ini secara terangterang telah menafikan kepandaian masyarakat tempatan (local genius) di dalam membina sesuatu tamadun tempatan. ${ }^{41}$ Antara budaya asing yang kononnya telah mencirikan kebudayaan Melayu adalah Hindu-Budhha, Arab, India dan Parsi. Bahkan apabila mengkaji pengaruh Islam terhadap jati diri orang Melayu, mereka telah mengambarkannya secara skeptik dengan mengatakan bahawa masyarakat Melayu sebenarnya tidak mempunyai pegangan keIslaman yang cukup kuat, hanya di lapisan kulit luar semata-mata, sedangkan isi dalamnya masih lagi berteraskan budaya pra Islam (animisme dan Hindu). ${ }^{42}$

\section{Kerjasama Kolonialisme Dan Orientalism Dalam Ilmu Kolonial.}

Teori negatif orientalis barat tentang Islam dan penganutnya diperkukuhkan hujahnya dengan bantuan rekord kolonial yang beroperasi di

35 Abu Hassan Sham dan Mariyam Salim (1995), Sastera undang-undang, Kuala Lumpur, h. xi-xxi.

${ }^{36}$ Rahimin Affandi Abdul Rahim (1999), Islamic legal reform in the administration of Islamic law in Malaysia : A critical analysis, tesis Ph.D untuk University of Birmingham, h. 332334.

${ }^{37}$ F. Swettenham (1895), Malay sketch, Singapore h.3.

${ }^{38}$ F. Swettenham(1955), British Malaya, London, h. 136-141.

${ }^{39}$ Rahimin Affandi Abdul Rahim (1995), "Budaya Taqlid Di Dalam Masyarakat Melayu : Suatu Tinjauan Ringkas ", dalam Jurnal Syariah, v. 3, bil. 1, h. 37-38.

40 Zainal Kling (1994), Antropologi tafsiran : sumbangan kebudayaan Melayu kepada teori, Syarahan perdana untuk pengukuhan profesor, Kuala Lumpur, h. 8-10.

${ }^{41}$ Bryan S. Turner (1964), " Gustave E. Von Grunebaum and the mimesis of Islam ", dalam Orientalism, Islam And Islamist, h.193-202.

${ }^{42}$ J.C. Leur (1955), Indonesian trade and society, The Hague, h. 169; K.P. Landon (1949), Southeast Asia : Crossroad of religions, Chicago, h. 134-164. 
Tanah Melayu. Maknanya, usaha penolakan sarjana Melayu Islam semasa terhadap ilmu kolonial mempunyai serampang dua mata; penolakan terhadap teori orientalis dan precedent kolonial sekaligus. Ini kerana orientalism adalah hasil ataupun anak yang lahir daripada kolonialism. Penjajah kolonial barat dengan bantuan sarjana-pentadbir orientalis di Tanah Jajahan mampu menaklukkan ruang geo-politik dan epistemologi masyarakat tanah jajahan menggunakan genre orientalism. Mereka telah membangunkan ilmu kolonial berasaskan kerangka epistemologi rationalism bagi membincangkan tentang agama : budaya, alam sekitar, tanah tanih, struktur masyarakat, bahasa dan sebagainya. Kerangka asas keilmuaan kolonial ini sebagai konstruksi ilmu masih lagi dipakai sehinggalah selepas Malaysia mencapai kemerdekaan. Hal ini dijelaskan oleh Shamsul Amri Baharuddin; ${ }^{43}$

"Kalau kita singkap kembali sejarah imperialism dan kolonialisme barat kita akan bertemu dengan bukti jelas tentang peri pentingnya ilmu dan analisis sosial untuk. pemerintahan. Misalnya, ilmu kolonial atau colonial knowledge, cukup penting untuk. sesebuah kuasa imperialis mengasaskan kekuasaannya di kawasan jajahannya. Kalau kekuatan ketenteraannya membolebkan sebarang kuasa penjajah menakluki secara fizikeal sesebuah ruang geo-politik, melalui ilmu kolonial pula penjajah tersebut mampu menakluki ruang epistemologi, iaitu ruang sistem pemikiran and intelektual masyarakat peribumi yang dijajah. Bak aur dengan tebing, kedua-dua komponen tersebut, yang terdapat dalam proses penaklukan-penjajahan ini, tersulam satu and sukar untuk dipisabkan."

Kebetulannya, pembinaan ilmu kolonial ini berlaku pada masa disiplin orientalism dibangunkan oleh sarjana orientalis di Eropah. Bahkan ada sesetengah sarjana-pentadbir British dan Belanda di Alam Melayu yang kemudiannya dilantik menjadi tokoh akademik orientalis untuk kajian rantau Alam Melayu di institusi pengajian tinggi di Eropah. Kajian keagamaan yang diamalkan oleh orientalis barat pada dasarnya berasaskan kepada epistemologi emperikal-induktif sekular (anti agama). ${ }^{44}$ Dalam paradigma epistemologi ini, sesuatu kajian terhadap Islam perlu menggunakan beberapa langkah yang utama, seperti;

Pertama, penetapan premis bahawa agama Islam adalah agama yang salah dan tidak betul, bersesuaian dengan teori evolusi Darwin yang menganggap

43 Shamsul Amri Baharuddin (1983), " Perancangan Pembangunan Negara Selepas Merdeka 1957-1975 : Tinjauan Sejarah Perkembangan Sosio-Ekonomi Malaysia”, Dalam Malaysia : Sejarah Dan Proses Pembangunan, Kuala Lumpur, h. 337-339.

${ }^{44}$ William J. Goode and Paul K. Hatt (1952), Methods In Social Research, h. 7. 
bahawa tamadun sekular barat adalah merupakan tamadun kemanusian yang paling maju dan tinggi, berasaskan pendekatan yang menolak sebarang bentuk ajaran agama. ${ }^{45}$ Mengikut teori ini, mana-mana masyarakat, khususnya masyarakat timur yang masih mengamalkan sesuatu agama berada di dalam kelompok masyarakat primitif, yang tertipu dengan pengajaran keagamaan. Bahkan mereka menggangap bahawa penderitaan manusia adalah berpunca dari kelemahan manusia yang tertipu dengan berpegang kepada kepercayaan keagamaan. ${ }^{46}$ Dalam soal ini, Mohd Kamal Hassan menjelaskan " mereka mempunyai sikap yang tidak senang terhadap agama dan menganggap penerusan bidup agama dalam dunia moden samada sebagai a relic of medieval obscurantism atan sebagai satu daripada manifestasi primitivism dan irrationality dalam diri manusia." ${ }^{\text {47 }}$

Kedua, penetapan bahawa Islam tidak harus dipelajari sebagai agama wahyu daripada langit, tetapi sebagai suatu agama budaya yang dihasilkan oleh masyarakat primitif timur tengah. ${ }^{48}$ Ringkasnya pemahaman mereka terhadap Islam lebih berbentuk ajaran agama yang difahami dari kaca mata sekular diharapkan akan ditiru oleh masyarakat timur yang lain. Selanjutnya mereka akan berusaha menafikan sumbangan bernilai yang diberikan oleh ajaran Islam ke arah mewujudkan tamadun kemanusiaan yang berharga. ${ }^{49}$ Hal ini secara jelasnya tidak terhad kepada impikasi dan proses Islamisasi di kawasan timur tengah, bahkan turut dilanjutkan penafiannya terhadap kawasan luar timur tengah (termasuklah dunia Alam Melayu) yang dilihat telah terpengaruh secara berkesan dengan ajaran Islam.

Ketiga, penggunaan kaedah penyelidikan ilmiah sains sosial barat sebagai satu-satunya cara untuk mendapatkan ilmu yang paling tepat dan betul, yang kononnya dibuat melalui kaedah yang cukup sistematik, teliti dan objektif. ${ }^{50}$ Manakala pengkajian agama yang berpandukan sumber wahyu akan dianggap

\footnotetext{
45 Maryam Jameelah (1971), Islam And Orientalism, Lahore, h. 122-123.

${ }^{46}$ Idris Zakaria (1999), “ Intelek Eropah Dan Penentangan Terhadap Agama ", dalam Al-Maw'izah, bil. 7, h. 15-21.

47 Mohd Kamal Hassan (1996), “ Pembentukan Ilmu Kemasyarakatan Dari Perspektif Islam “, dalam Sains Sosial Dari Perspektif Islam, Kuala Lumpur : DBP, h. 13.

48 Shukri Ahmad (1998), "Agama Dan Masyarakat ", dalam Pengenalan Kepada Sains Sosial, Kuala Lumpur, h. 194-195.

49 Berthold Spuler (1960), The Muslim World : A Historical Survey, Leiden, part 1, h. 5657.

50 Mohd Natsir Mahmud (1997), Orientalisme : Al-Quran Di Mata Barat ( Sebuah Studi Evaluatif), Semarang, h. 10-12.
} 
sebagai tidak saintifik dan tidak boleh dibuktikan secara emperikal (semua perkara yang boleh ditangani secara lahiriah dengan pancaindera). ${ }^{51}$ Pendekatan ini pada dasarnya berpunca dari sikap mereka yang menolak agama dan perkara-perkara ghaib yang tidak dapat dilihat dan ditangani dengan pancaindera. ${ }^{52}$

Sebagai ganti kepada sumber wahyu yang dianggap sebagai tidak saintifik, seseorang pengkaji Islam perlu bergantung sepenuhnya kepada akal yang bebas, dengan menerima pakai teori-teori yang dikemukakan oleh tokohtokoh orientalis barat yang rata-ratanya terpengaruh dengan fahaman sosiologi barat (aliran kapitalisme dan sosialisme). ${ }^{53}$ Apa yang jelasnya, penolakan terhadap sumber wahyu ini telah mendorong mereka untuk memberikan penjelasan yang kabur dan bias terhadap ajaran Islam. ${ }^{54}$

\section{Berasaskan kepada paradigma ini kita boleh melihat pelbagai teori yang telah dikemukakan oleh tokoh orientalis barat, antaranya ;}

1. Islam adalah agama yang terhasil dari budaya timur tengah yang memerlukan suatu kerangka yang agak keras dan unik bersesuaian dengan latar belakang iklim dan masyarakat timur tengah, yang sudah pasti tidak sesuai untuk masyarakat yang bukan arab. ${ }^{55}$

2. Nabi Muhammad adalah seorang yang oportunis, yang menyebarkan ajaran Islam hanya kerana dorongan ekonomi dan keinginan untuk mendapatkan harta rampasan perang. Atas dasar ini Nabi Muhammad telah menjalankan operasi ketenteraan yang berorientasikan keinginan feudal untuk menguasai tanah yang luas. ${ }^{56}$ Ini juga menunjukkan bahawa agama Islam adalah agama yang mengutamakan kekerasan (terror) yang harus ditakuti oleh masyarakat lain. $^{57}$

\footnotetext{
${ }^{51}$ Abdul Rahman Abdullah (2000), Wacana Falsafah Sejarah : Perspektif Barat Dan Timur, Kuala Lumpur, h. 71-72.

${ }^{52}$ Louay Safi (1998), Asas-Asas Ilmu Pengetabuan : Satu Kajian Perbandingan Kaedab-Kaedah Penyelidikan Islam Dan Barat, terj. Nur Hadi Ihsan, Kuala lumpur, h. 190-199.

${ }^{53}$ Mohd Kamal Hassan, " Pembentukan ilmu kemasyarakatan ", h. 12-14.

${ }^{54}$ Syed Muhammad Dawilah al-Edrus (1999), Epistemologi Islam; Teori Ilmu Dalam AlQuran, Kuala Lumpur, h. 14.

55 W.M. Watt (1954_, " Economic And Social Aspects Of The Origin Of Islam “, dalam The Islamic Quarterly, v. 1, no. 1, h. 97.

${ }_{56}$ Bryan Turner (1983), Weber Dan Islam, Jakarta, h. 20 dan 56.

${ }^{57}$ Edward Said (1978), Orientalism, London, h. 77.
} 
3. Islam dinisbahkan sebagai Muhammadanism yang diasaskan oleh Nabi Muhammad hasil peniruan yang dibuat dari agama Yahudi dan kristian. Hal ini juga mendorong mereka mengatakan bahawa Islam adalah suatu kumpulan agama Kristian yang sesat. ${ }^{58}$

4. Asal usul ajaran Islam yang kononnya berpunca dari al-Quran sebenarnya bersumberkan kepada pengaruh dan kitab agama Kristian dan Yahudi. ${ }^{59}$

Keempat, keperluan untuk memilih sumber bahan kajian tentang ajaran Islam yang rapi dan tidak bersifat berat sebelah. Suatu bentuk piawaian kualiti yang agak ketat telah dikenakan kepada sesuatu sumber bahan yang membabitkan kajian Islam. ${ }^{60}$ Walaupun dalam soal ini mereka begitu teliti dan cerewet di dalam menilai kebenaran dan kesahihan karya-karya yang dihasilkan oleh sarjana Islam silam, pada masa yang sama juga mereka telah bersikap liberal dan tidak mengikuti ketetapan piawaian ini apabila menerima pakai sumber bahan milik sarjana orientalis silam yang kebanyakannya dibuat berasaskan kepada fantasi, cerita dogeng ${ }^{61}$ dan semangat anti Islam yang melampau sebagai akibat dari peristiwa Perang salib. ${ }^{62}$

Kelima, sebarang penganalisaan kritikal terhadap ajaran Islam perlu dibuat menggunakan pendekatan bigher criticism. Pendekatan ini pada mulanya digunakan untuk membuktikan kesilapan yang terdapat di dalam agama kristian, kemudiannya telah turut diperpanjangkan kepada agama Islam. Berasaskan pendekatan ini mereka telah cuba membuktikan kesilapan kandungan Quran dan Sunnah yang secara pastinya bermotifkan matlamat untuk menunjukkan Islam sebagai agama yang salah. ${ }^{63}$ Apatah lagi Islam telah disamatarafkan dengan agama budaya dunia yang lain, yang terhasil bukannya daripada wahyu Allah, tetapi kerana faktor budaya masyarakat setempat. ${ }^{64}$

\footnotetext{
${ }^{58}$ R.W. Southern (1962), Western Views Of Islam In The Middle Ages, Harvard, h. 38.

${ }^{59}$ James E. Royster (1972), “ The Study Of Muhammad : A Survey Of Approaches From The Perspective Of The History And Phenomenology Of Religion “, Dalam The Muslim World, v. 62, h. 57 dan 61.

60 Abdul Rahman Abdullah (1994), Pengantar Ilmu Sejarah, Kuala Lumpur, h. 76-77.

${ }^{61}$ Norman Daniel (1966), Islam, Europe And Empire, Edinburgh, h. 6.

${ }^{62}$ E.E. Calverley (1958), Islam : An Introduction, The American University in Cairo Press, h. 2-3.

${ }^{63}$ Ibid, h. 83-84.

64 Shukri Ahmad (1998), “ Agama Dan Masyarakat “, Dalam Pengenalan Kepada Sains Sosial, Kuala Lumpur, h. 194-195.
} 
Elemen sekularisme (anti agama) yang terkandung di dalam pendekatan ini amat jelas sekali, yang menetapkan bahawa sesuatu peristiwa sejarah yang berlaku di dalam masyarakat Islam perlu dinilai secara negatif demi untuk mendapatkan sesuatu fakta yang sebenar. Pecahan dari pendekatan higher criticism yang dikenali sebagai kaedah historicism perlu dipakai sepenuhnya di dalam membuat penelitian ilmiah terhadap sesuatu peristiwa sejarah umat Islam. Kaedah historicisme ini mempunyai dua elemen yang amat negatif kerana terpengaruh dengan fahaman sekularisme yang menggangap agama adalah sebagai fenomena yang tidak saintifik yang perlu ditolak di dalam sesuatu perkiraan akademik. Melalui kaedah ini, dua perkara penting telah ditetapkan;

1. Untuk memahami sesuatu fakta sejarah kita perlu melakukan penelitian yang rapi terhadap asal usul sesuatu peristiwa tersebut. ${ }^{65}$ Akan tetapi pencarian asal usul ini terhenti kepada dunia fizik semata-mata dan menolak alam supra rasional seperti wahyu Allah. ${ }^{66}$

2. Huraian terhadap peristiwa sejarah yang bersifat anti alam Ghaib (non fizik) menyebabkan manusia terpaksa bergantung sepenuhnya dengan akal di dalam mencari sebab musabab terhadap lingkungan empirik atau dunia fizik sesuatu peristiwa yang berlaku. ${ }^{67}$

\section{Keperluan Mendedahkan Pengaruh Legasi Ilmu Kolonial Yang Menjejaskan Pengaruh Islam Di Malaysia.}

Di zaman selepas merdeka, pihak penjajah British secara halus telah memastikan ilmu kolonial ini akan tetap dipakai oleh masyarakat tanah jajahan. Warisan ini berjaya dilakukan memandangkan hanya elit penjajah (raja dan pembesar Melayu) yang dirangka menjadi penganti penjajah sebagai pemimpin negara. ${ }^{68}$ Maknanya, pihak British memang telah menjangka bahawa warisan british ini akan dicabar suatu hari nanti oleh masyarakat Melayu-Islam. Untuk itu, mereka telah memastikan warisan kolonial ini sebaik mungkin, melalui

\footnotetext{
${ }^{65}$ Friedrich Meinecke (1956), " Historicism And Its Problems “, Dalam The Varieties Of History, New York, h. 278.

${ }^{66}$ Ibid.

${ }^{67}$ Maurice Mandelbaum (1986), “ Historism “, dalam The Encyclopedia Of Philosophy, v. iv, h. 24.

${ }^{68}$ Khasnor Johan (1983), " Perkhidmatan Tadbir Melayu : Tradisi Dan Peranan Dalam Konteks Kerajaan Penjajah “, dalam Malaysia : Sejarah Dan Proses Pembangunan, Kuala Lumpur : Persatuan Sejarah Malaysia, h. 134-145.
} 
pemilihan elit politik dan sistem pendidikan barat yang kondusif dengan hasrat mereka.

Hal ini memang terbukti benar apabila pewaris ini tetap meneruskan polisi penjajah dalam beberapa dasar. ${ }^{69}$ Antaranya boleh dilihat kepada bentuk Perlembagaan negara, pemakaian buku teks di sekolah, universiti mengikut perspektif British, ${ }^{70}$ sistem pemerintahan negara mengikut gaya Westmister, pentadbiran awam dan pentabiran undang-undang bernegara. Lebih parah lagi, ilmu kolonial ini disebarkan kepada pihak IPT eropah dan badan antarabangsa sebagai bahan ilmiah yang paling berotoriti. Ia berupa pelbagai kajian yang membabitkan latar belakang manusia Alam Melayu dalam bentuk laporan, hasil bancian, jurnal ilmiah, catatan peribadi, bibliograpi dan manuscript.

Usaha reformasi-Islamisasi terhadap warisan kolonial telah giat dilakukan oleh sarjana Melayu selepas merdeka. Terpenting sekali, usaha Islamisasi ini perlu dilakukan melalui saluran politik dan penyelidikan ilmiah di peringkat IPT. Maknanya, untuk konteks Malaysia, usaha ini hanya mampu dilakukan melalui kuasa ilmu dan komitmen politik, dan tidak boleh dilakukan secara retorik kosong semata-mata. Lebih tepat lagi, usaha ini boleh dikatakan sebagai prioriti utama (fiqh Awlawiyyah) sesuai dengan kehendak maqasid.

Hasil reviewing pengaruh ilmu kolonial di Malaysia, terdapat beberapa perkara yang boleh ditonjolkan. Antaranya;

1. Mahkamah syariah sesuai dengan dasar British telah diletakkan pada kedudukan yang lebih rendah daripada Mahkamah Sivil. Keputusan mahkamah syariah dan fatwa boleh diatasi oleh mahkmah sivil. Secara terang-terangan kita dapat mengesan pendekatan British yang cuba menunjukkan bahawa Islam berstatus rendah dan tidak mampu digunakan untuk menyelesaikan masalah hukum amali di Tanah Melayu. Paradigma ini kekal dan diteruskan oleh pembuat dasar di Malaysia selepas merdeka. Kemudiannya, usaha reformasi sistem perundangan Islam di Malaysia telah dijadikan agenda ataupun prioriti utama (walaupun ianya tidak diberi nama Awlawiyyah) oleh Profesor Ahmad Ibrahim. Beliau telah menjalankan pendekatan yang berhikmah dengan menjalinkan hubungan positif dengan pihak kerajaan. Hasilnya, pelbagai cadangan reformasi agensi perundangan

69 Shaharuddin Maaruf (1993), Konsep Wira Dalam Masyarakat Melayu, Singapura : Pustaka Antara, h. 99-116.

70 A.J. Stockwell (2009), The Crucible Of The Malayan Nation : The University And The Making Of A New Malaya. 1938-1962, Modern Asian Studies, v. 43, 5, h. 11491187. 
Islam telah diterimapakai oleh pihak kerajaan. Apa yang dapat dipelajari daripada precedent ini adalah kebijaksanaan Profesor Ahmad Ibrahim telah mempergunakan sepenuhnya;

a. Konstektual sosial politik Malaysia era tahun 1970an-1990an yang menyaksikan masyarakat dan pihak kerajaan begitu terbuka dan menerima baik semangat kebangkitan Islam. Jadi, berasaskan semangat ini yang ditambah pula dengan tren politik hukum pihak kerajaan yang baik dan kondusif untuk agenda Islam; usaha reformasi agensi ini berjaya dilakukan.

b. Usaha ini menggunakan sepenuhnya penyelidikan ilmu berbentuk blue print lengkap tentang apa dan bagaimana reformasi dapat dilakukan. Hal ini mustahil dilakukan andainya beliau tidak memaklumi butiran negatif yang terdapat dalam warisan kolonial di Tanah Melayu.

2. Islam dalam perlembagaan Malaysia perlu ditafsirkan mengikut world-view sekular.

3. Pengajian Islam diletakkan pada kedudukan yang rendah, sebagai pecahan berada di bawah disiplin sains sosial. Mengikut amalan di Universiti Malaya selepas merdeka, pengajian syariah diletak di bawah fakulti UndangUndang yang telah diajar mengikut perspektif barat.

\section{Keperluan mengamalkan sikap selektif dengan genre orientalis-ilmu} kolonial.

Dalam tradisi pengajian Islam, terdapat suatu stigma yang menyatakan bahawa genre orientalisme secara mutlaknya dianggap sebagai negatif. Lebih kronik lagi, terdapat juga pandangan yang menisbahkan dunia Barat secara mutlak sebagai pusat kekuasaan gelap yang anti Islam $^{71}$ ataupun sebagai diabolisme (pengikut tabiat Syaitan) ${ }^{72}$ Lanjutan daripada pandangan ini, terdapat sesetengah kumpulan yang secara berani menyatakan bahawa sesiapa sahaja yang pernah belajar dan dilihat menyebarkan paradigma pengajian yang bersifat terbuka ataupun positif dengan pusat kajian orientalisme akan dituduh

\footnotetext{
${ }^{71}$ Lihat sebagai contohnya Adian Husaini (2005), Wajah Peradaban Barat, Jakarta : Gema Insani.

${ }^{72}$ Syamsuddin Arif (2008), Orientalis Dan Dianolisme Pemikiran, Jakarta : Gema Insan. h. $143-147$.
} 
sebagai tali barut orientalis yang harus ditentang habis-habisan, ${ }^{73}$ sehinggalah kepada peringkat sanggup mengkafirkan kalangan ini.

Apa yang menghairankan, pada masa terdapat pandangan yang mengutuk pusat dan genre kajian orientalisme ini, terdapat beberapa fakta yang perlu difikirkan bersama. Antaranya ialah pusat kajian orientalisme yang rata-ratanya berada di negara Barat telah dijadikan tumpuan oleh pelajar Islam dari seluruh dunia untuk meneruskan pengajian mereka di peringkat pasca siswazah. Daripada laporan yang diberikan oleh pelajar Islam sendiri yang pernah belajar di pusat terbabit, ternyata sekali pusat kajian tersebut memang mempunyai beberapa elemen positif seperti sistem pengajian yang agak berkesan, koleksi bahan perpustakaan ( kajian primari dan sekundar) yang cukup lengkap, iklim intelektual yang kondusif, penekanan yang lebih kepada soal metodologi kajian yang terkini dan terpenting sekali ianya terbukti mampu melahirkan para sarjana Islam yang kompeten. ${ }^{74}$

Selain itu, pusat kajian orientalism ini telah menjadi tumpuan pelarian politik oleh sejumlah besar sarjana Islam daripada negara umat Islam seperti Timur Tengah, Indo-Pakistan ${ }^{75}$ dan Iran. Pada masa mereka diburu dan dimusuhi oleh pemerintah umat Islam sendiri, kehadiran mereka telah diterima secara terbuka oleh pusat kajian orientalis ini, Sejarah mencatatkan bagaimana ramai daripada tokoh gerakan Islam yang ditindas oleh pemerintah negara umat Islam telah berhijrah ke negara Barat yang kemudiannya bertanggungjawab memperkembangkan semangat kebangkitan semula Islam di daerah baru yang amat kondusif (Civil society) yang mampu memberi ruang untuk memperkembangkan kebebasan intelektual. ${ }^{76} \mathrm{Hal}$ ini kemudiannya telah mempengaruhi sejumlah besar pelajar-pelajar Islam yang datang daripada pelbagai negara Islam. Mengikut analisis yang dibuat oleh seorang sarjana Barat

\footnotetext{
${ }^{73}$ Daud Rasyid (2002), Pembaruan Islam Dan Orientalisme Dalam Sorotan, Jakarta : Media Akbar, h. 117-125.

${ }^{74}$ Mohammad Kamil Abdul Majid (2008), Pusat Kajian Orientalism: Analisis Terhadap Sikap Umat Islam, dibentang dalam International Seminar On Research In Islamic Studies, Anjuran APIUM pada 17-18 Disember 2008

75 Kawasan geografi yang penduduk India dan Pakistan. Kawasan ini juga adalah merupakan majoriti umat Islam terbesar di dunia selepas Indonesia dan Timur Tengah.

76Rahimin Affandi Abd Rahim (2007), "Etika Kepimpinan Islam Dan Isu Pembangunan Di Malaysia : Satu Analisis ", dalam Prosiding Seminar Kepimpinan Islam Peringkat Antarabangsa, anjuran APIUM, pada 10-11 Julai 2007, h. 34-47
} 
yang mengikuti perkembangan pendidikan Islam di Malaysia, pada kebiasaannya apabila tokoh-tokoh yang terdidik dan mendapat latihan di peringkat ijazah tinggi dari kedua-dua pusat pengajian di atas (Timur Tengah dan Barat) kembali ke Malaysia, mereka akan berkhidmat di beberapa fakulti pengaijian Islam di universiti-universiti tempatan ${ }^{77}$.

Berasaskan kepada kesemua fakta ini, pendekatan Maqasid menuntut kita menilai genre orientalisme dengan perspektif yang lebih adil, terbuka dan selektif. Maknanya, kaedah penilaian yang sepatutnya bukanlah pendekatan anti melulu. Mengikut hemat penulis, paradigma ini memang mempunyai justifikasinya dalam sejarah tamadun keilmuan Islam sendiri. Hal ini ditegaskan dengan cukup tuntas oleh Wan Mohd Nor Wan Daud yang apabila meneliti tentang sikap yang terlalu negatif terhadap genre orientalisme, telah menegaskan bahawa terdapat sejumlah besar dari sarjana Islam sendiri yang telah dijangkiti penyakit westophobia, sikap takut dan benci yang tidak rasional terhadap barat. Pada dasarnya, penyakit ini adalah serpihan daripada penyakit akal, xenophobia yang menyebabkan penghidapnya sentiasa takut kepada unsur-unsur luar. ${ }^{78}$

\section{Keperluan Memperinci Dan Menjawab Elemen Negatif Dibawa Oleh Ilmu Kolonial Tentang Islam.}

\section{Gambaran Buruk Tentang Manusia Melayu.}

Pihak kolonial memang mengumpulkan manuskrip melayu-Islam yang amat banyak. Koleksi historigrafi milik masyarakat Melayu yang berupa manuskrip Melayu-Islam dalam kalangan akademik barat dianggap sebagai warisan yang sangat berharga. Ianya sejak sekian lama telah dijadikan sumber normatif ataupun bahan kajian utama untuk memahami dan memperihalkan tentang watak manusia Melayu-Islam. ${ }^{79}$ Ironisnya, pendedahan tentang watak dan pencapaian intelektual manusia Melayu-Islam yang difahami oleh sarjana barat melalui bahan kajian ini seringkali agak mengecewakan. Hal ini berlaku

\footnotetext{
77 Fred R. Von Der Mehden (1993), Two Worlds Of Islam: Interaction Between Southeast Asia And The Middle East, Florida, h. 83-85.

${ }^{78}$ Kata pengantar Wan Mohd Nor Wan Daud di dalam buku Syed Muhammad Dawilah al-Edrus (1999), Epistemologi Islam : Teori Ilmu Dalam Al-Quran, Kuala Lumpur : DBP, h. Xv.

${ }^{79}$ Rahimin Affandi Abd. Rahim (2005), “ Citra Islam Dalam Pembentukan Manusia Melayu Moden Di Malaysia : Suatu Analisa”, Jurnal Pengajian Melayu, v. 15, h. 19-51
} 
antara lainnya berpunca daripada kelemahan metodologi kajian manuskrip yang dipakai oleh genre orientalism barat. ${ }^{80}$

Dalam menghurai watak manusia Melayu melalui koleksi historigrafi ini, mereka sejak awal lagi (semacam pre conveived idea) menetapkan beberapa ciri utama yang kemudiannya diolah dengan pelbagai teknik; ${ }^{81}$

1. Ianya static dan abistorical. Orang Melayu sebagai static dan tidak boleh berubah. Pemikiran ahistorical enggan mengendahkan perubahan yang boleh berlaku dalam persekitaran dan budaya sesuatu masyarakat dari zaman ke zaman. Ia dianggap sebagai sifat semulajadi orang Melayu yang static dan tidak berubah ke arah kebaikan.

2. Mutunya rendah, simple, primitif dan irrasional, tetapi bersifat eksotik dan memukau.

3. Bersifat sterotaip dalam bentuk prejudis ras yang ketara. Watak orang Melayu disifatkan malas, fatalis, berpuashati dengan apa yang dimiliki dan berlaku kerana factor genetic yang rendah. Sifat utama kajian-kajian ini mendedahkan dan menyebarkan propaganda kononnya masyarakat Melayu adalah bersifat negatif seperti malas, ${ }^{82}$ suka berpoya-poya, ${ }^{83}$ keras kepala, ${ }^{84}$ tidak boleh diharap, ${ }^{85}$ suka berhutang ${ }^{86}$ dan sebagainya.

4. Huraian dalam bentuk reduksionis yang merendahkan orang Melayu, tanpa dikaji apakah sebab kemunduran berlaku kepada orang Melayu.

5. Keasyikan kajian mereka lebih ditumpukan kepada kajian tekstual (filologikal). Ia merupakan usaha mengedit teks yang ditransliterasi dan pencarian kepada versi-versi teks yang asli. Mereka lebih asyik menghurai leksikon dan perubahan simantik yang terdapat dalam teks. Bagi mereka, dengan mengkaji teks, hanya dengan analisis perkataan dan lapisan

80 Mohd FarhanAbd Rahman (2012), “ Pandangan Orientalis Terhadap Masyarakat Islam Di Tanah Melayu: Analisa Terhadap Karya Pilihan R.O. Winstedt", dalam Jurnal Figh, 2012.

81 Azhar Ibrahim Alwee (2002), Orientalisme Dalam Pengajian Melayu, Dalam Persidangan Antarabangsa Bahasa, Sastera Dan Kebangsaan Melayu Ke 2, Anjuran Jabatan Bahasa Dan Kebudayaan Melayu, Kumpulan Akademik Bahasa Dan Kebudayaan Asia, Institute Pendidikan Nasional, Pada 1-3hb September 2002.

82 A. Wright dan T.H. Reid (1912), The Malay Peninsula, Londom, h. 315.

${ }^{83}$ E. G. De Eredia (1930), "The description of Malaca ", dalam JMBRAS, v. 8:1, h. 31.

${ }^{84}$ T.S. Raffles (1930), Memoir of the life and public services of Sir Stamford Raffles, London, v. 1, h. 91 dan 288-289.

85 W. L. Richmond (1928), The Modern Malay, London, h. 95 dan 223.

${ }^{86}$ F. Swettenham (1895), Malay sketch, Singapore, h. 2-3. 
etimologinya mereka akan menemukan rahsia mengapa orang Melayu berfikir dan bertindak. Ianya dibuat tanpa mempedulikan kondisi sejarah dan suasana masyarakat yang berkaitan.

6. Mengabaikan penggunaan pendekatan sains sosial diagnostic. Bagi mereka, pendekatan sains social agak janggal untuk digunakan mengkaji fenomena social orang Melayu.

7. Elemen keunggulan pencapaian manusia Melayu akan dilenyapkan. Sebaliknya hal pencapaian ini dikaitkan dengan usaha gigih kolonialis menjajah dan mentamadunkan orang Melayu.

Hal ini ternyata amat salah sekali keranan kajian tentang objek kemanusiaan perlu menggunakan beberapa paradigma utama; mechanism, oragnism dan konstektual. Hal ini bersesuaian dengan tren perubahan paradigma keilmuaan yang secara lantang disuarakan oleh banyak pihak. Ianya terdiri dari pendekatan; ${ }^{87}$

1. Mechanism; pendekatan yang lebih terbuka berbanding pendekatan legal formalistic (Formism), yang memberikan penekanan kepada sifat pokok sesuatu mechanisme iaitu soal kontinuiti dan mekanis. Menurut paradigma ini semua gejala kehidupan adalah bersifat bersinambungan dalam proses mekanis yang terus bergerak. Ianya paling disesuai diterapkan dalam kerangka kajian yang membabitkan elemen kemasyarakatan, memandangkan masyarakat manusia bukannya static dan selalu berubah, samada ke arah yang lebih baik ataupun sebaliknya.

2. Organism ; seluruh realiti kehidupan pada dasarnya berjalan secara harmonis, integrated, penuh perkaitan antara faktur dalaman dan luaran serta penuh dengan kepastian. Atas dasar ini, kaedah terbaik untuk memahami realiti kehidupan manusia perlu mengabungkan kesemua bentuk disiplin keilmuan, seperti sejarah, sosiologi, ekonomi dan sebagainya. Jadi, sebarang usaha untuk menilai manuskrip Melayu perlu dilihat kepada pelbagai aspek kehidupan seperti aspek budaya, sosiologi, agama, politik dan ekonomi sekaligus.

3. Konstektual; semua fenomena kemanusiaan yang dikaji adalah bersifat kontekstual, tidak ada satupun dalam kehidupan ini yang tidak berkait dengan konteks dan kondisinya yang bersifat khusus. Atas dasar ini, kajian terhadap elemen manusia akan menjadi lebih mendalam sekiranya dilihat

87 Prof Dr Mastuhu (1998), “ Penelitian Agama Islam : Perspektif Antar Disiplin Ilmu : Tinjauan Disiplin Sosiologi ', Dalam Tradisi Baru Penelitian Agama Islam : Tinjauan Antar-Disiplin Ilmu, Bandung : Penerbit Nuansa, h. 91-104 
kepada aspek konstektual sesuatu objek yang dikaji. Hasilnya, kita bakal mengetahui bahawa latar belakang masyarakat Melayu silam itu wujud adalah bersifat khusus yang hanya sesuai dengan reality masyarakat tradisi berbanding dengan kawasan lain.

Selepas merdeka, pendekatan stereotype ras yang menetapkan pelbagai sifat negatif kepada semua lapisan kaum di Malaysia terus kekal dan disebarkan ke peringkat antarabangsa. Bangsa Melayu dikatakan sebagai bangsa yang malas, suka berkhayal dan tidak boleh dipercayai, bangsa Cina dinisbahkan sebagai bangsa pencandu dan suka berjudi dan bangsa India pula dinisbahkan sebagai bangsa yang lemah daya intelektual, pengotor dan kuat minum arak. Pendedahan yang bersifat stereotype ini bakal menyebabkan semua bangsa Malaysia akan merasa malu dan hilang maruah diri untuk berhadapan dengan bangsa lain di dunia ini. Apa yang lebih buruk lagi, masyarakat Malaysia selepas merdeka akan beranggapan bahawa semua warisan silam bangsa mereka bersifat rendah dan ketinggalan zaman berbanding dengan warisan yang ditinggalkan oleh warisan tamadun barat, yang juga dikenali sebagai pendekatan euro-centric. 88

\section{Penafian Terhadap Peranan Islam Di Alam Melayu}

Dalam soal ini, sarjana-pentadbir kolonial mendokong teori Islamisasi daripada India bagi memperlihatkan bentuk ajaran Islam yang sampai ke Alam Melayu dalam bentuk yang tidak murni. Bagi mereka, Islam yang datang ke Alam Melayu ini pada peringkat awalnya bukanlah dalam bentuknya yang sejati tetapi telah dicirikan dengan beberapa aspek negatif melibatkan para mubaligh yang awal. ${ }^{89} \mathrm{Hal}$ ini dapat dilihat dalam beberapa keadaan:-

1. Citra Islam yang terpengaruh dengan tamadun era Taqlid di dalam dunia intelektual Islam.

2. Islam dalam bentuk kesufian yang kurang menitikberatkan persoalan rasionalisme.

3. Citra Islam yang penuh dengan ciri-ciri popular Islam yang dibawa oleh mubaligh awal.

\footnotetext{
${ }^{88}$ Arba’iyah Mohd Noor (2001), “ Pensejarahan Di Dalam Tradisi Barat Dan Melayu : Satu Perbandingan Ringkas", Dalam (Edit) Redzuan Othman, Jendela Masa, Kuala Lumpur : Penerbit UM, h. 26-27.

89 Aliza Elias (2012), " Kecenderungan Paksi India : Implikasinya Terhadap Pensejarahan Islam Di Alam Melayu", Mohd Zaidi Ismal (Edit) Adab Dan Peradaban : Karya Pengi'tirafan Untuk Syed Muhammad Naquib Al-Attas, MPH publishing, h. 609-627.
} 
4. Citra Islam yang terpengaruh dengan ciri-ciri feudalism timur tengah dan India.

Mereka secara berlebihan mendakwa Islam tidak memberi apa-apa kesan positif kepada masyarakat Melayu, berbanding dengan proses Indianisasi Alam Melayu sebelumnya. Bahkan pengaruh Indianisasi dilihat lebih positif di dalam membawa elemen tamadun kepada masyarakat Alam Melayu. Hal ini dinilai daripada segi wujudnya artifak hebat, wujud masyarakat yang damai dan tidak memusuhi kuasa barat. ${ }^{90}$ Lebih penting lagi, mereka berlebihan mengagungkan tamadun kebendaan dan sastera hindu kepada masyarakat Alam Melayu, walaupun kesemuannya tidak mengandungi penggunaan daya artikulasi kritikal dalam kehidupan bermasyarakat.

Sarjana kolonial sering menegaskan bahawa proses Islamisasi Alam Melayu yang diusahakan oleh mubaligh yang awal penuh dengan paksaan dan tipu muslihat, serta mengajar masyarakat Alam Melayu untuk bersikap ganas pada golongan bangsa Eropah sebagai akibat daripada semangat Perang Salib yang berlaku di Timur Tengah. Mereka menilai undang-undang Islam yang diamalkan dalam masyarakat Melayu sebagai ketinggalan zaman dan hanya sesuai dipakai untuk konsteks masyarakat Timur Tengah abad pertengahan. ${ }^{91}$

Mereka menegaskan bahawa Islam tidak memberi apa-apa impak positif kepada masyarakat Melayu. Bahkan pengaruh pra Islam (hindu-budhha dan animisme) dianggap lebih baik berbanding dengan Islam. Hal ini ditegaskan oleh raffles berulang kali walaupun dia memaklumi pencapaian intelektual ulamak Islam di abad 16-17 dengan penghasilan karya kitab jawi. Hal ini terbukti apabila dia menjalankan polisi mendapatkan sebanyak mungkin manuskrip Islam daripada masyarakat Melayu, dengan melantik Abdullah Munsyi sebagai agen untuk usaha pengumpulan manuscript Melayu Islam ini. Boleh dikatakan sebahagian besar daripada koleksi manuscript Melayu Islam di British muzuim sebagai hasil usaha beliau. ${ }^{92}$

90 Mohd Zariat Abdul Rani (2005), Antara Islam Dan Hinduisme Di Alam Melayu : Beberapa Catatan Pengkaji Barat, SARI, v. 23, h. 67-82.

${ }^{91}$ Mohd FarhanAbd Rahman (2012), “ Pandangan Orientalis Terhadap Masyarakat Islam Di Tanah Melayu: Analisa Terhadap Karya Pilihan R.O. Winstedt”, dalam Jurnal Fiqh.

92 Syed Muhd Khairudin Al-Junied (2003), From Noble Muslims To Saracen Enemies : Thomas Stamford Raffles's Discourse On Islam In The Malay World, SARI, 21, h. 13-29. 
Raffles mengeluarkan pandangan bahawa andainya tradisi Hindu masih berkuasa sudah pasti tamadun Melayu akan menjadi maju. Hal ini terbukti dengan wujudnya monumen Hindu seperti Candi Borobudur yang sangat hebat. Sedangkan Islam tidak mempunyai kesemua monumen ini. Dalam banyak hal, ia menghargai budaya hindu yang menekankan kasta kerana ketaatan masyarakat bawahan kepada kasta atasan akan memudahkan kuasa british menguasai politik-ekonomi masyarakat tanah jajahan. Lebih penting lagi, dalam agama hindu tiada fahaman jihad melawan penjajah yang bakal menjejaskan kuasa penjajah british.

Mereka secara berlebihan mendakwa Islam tidak memberi apa-apa kesan positif kepada masyarakat Melayu, berbanding dengan proses Indianisasi Alam Melayu sebelumnya. Bahkan pengaruh Indianisasi dilihat lebih positif di dalam membawa elemen tamadun kepada masyarakat Alam Melayu. Hal ini dinilai daripada segi wujudnya artifak hebat, wujud masyarakat yang damai dan tidak memusuhi kuasa barat. ${ }^{93}$ Lebih penting lagi, mereka berlebihan mengagungkan tamadun kebendaan dan sastera hindu kepada masyarakat Alam Melayu, walaupun kesemuannya tidak mengandungi penggunaan daya artikulasi kritikal dalam kehidupan bermasyarakat.

\section{Sikap Skeptikal Terhadap Peranan Sejarah Islam Di Alam Melayu.}

Sarjana orientalism secara terang-terangan menafikan otoriti sumber sejarah tempatan Alam Melayu yang dikatakan penuh elemen feudalism dan mitos. Bagi mereka, sumber sejarah Alam Melayu merangkumi Hikayat Raja Pasai, Sejarah Melayu, Hikayat Aceh, Hikayat Siak, Tuhfat Al-Nafs dan sebagainya tidak mengandungi apa-apa faedah yang mengambarkan latar belakang sosiopolitik-ekonomi dan intelektual masyarakat Alam Melayu. Hal ini telah diulas dengan cukup baik oleh Dr. Tantiana A. Denisova dan Hussain Othman yang mendedahkan mutu intelektual yang terkandung di dalam kesemua sumber sejarah Alam Melayu ini. ${ }^{94}$

Dirujuk kepada elemen epistemologi-metodologinya, genre orientalism telah melakukan beberapa kesilapan utama dalam menilai sember sejarah Islam tempatan, termasuklah kepada sumber ajaran Islam itu sendiri. Pertama, mereka melakukan pemaksaan pemakaian konsep sejarah barat di dalam menilai sumber sejarah Alam Melayu. Antara keduanya, ternyata sekali world-view

${ }^{93}$ Mohd Zariat Abdul Rani (2005), Antara Islam Dan Hinduisme Di Alam Melayu : Beberapa Catatan Pengkaji Barat, $S A R I$, v. 23, h. 67-82.

${ }^{94}$ Hussain Othman (2008), Conceptual Understanding Of Myths And Legends In Malay History, SARI, v. 26, h. 91-110. 
pegangannya tidak sesuai dengan konstektual Alam Melayu. Bagi mereka, berasaskan falsafah racism euro-centric, hanya kerangka epistemologi konsep sejarah mengikut pemahaman barat sahaja yang dianggap paling betul secara mutlaknya.

Kedua, sebelum kedatangan kuasa kolonial, masyarakat Alam Melayu dianggap tidak memiliki sejarah yang jelas, kabur dan bersifat tradisional. Andainya dilakukan kajian mendalam, ia menunjukkan beberapa perkara;

1. sebelum mereka datang, orang Melayu tidak bertamadun seterusnya mengajar orang Melayu jangan mempercayai sejarah keunggulan silam. Sebaliknya ia harus dilupakan dan cukup bergantung pada british untuk membawa kemajuan.

2. kedatangan mereka adalah untuk menyelamatkan orang Melayu daripada kejahatan sendiri. Mereka ingin menunjukkan bahawa kedatangan mereka membawa maksud yang murni dan menyembunyikan niat jahat mereka ingin menjajah dan mengaut hasil bumi masyarakat Melayu. Jadi mereka menciptakan teori kejahatan sistem feudal Melayu yang menindas ahli masyarakat. Jadi, bagi menutup kejahatan sendiri mereka menuduh masyarakat Melayu yang jahat.

3. kononnya hanya sumber catatan mereka sahaja yang bermutu objektif dan boleh dipercayai kerana sumber sejarah tempatan penuh dengan elemen mitos. Sedangkan catatan sejarah mereka penuh dengan kelemahan merangkumi; a) tidak mendalam dan dibuat secara sepintas lalu; b) sarat dengan agenda British yang hanya terhad tentang Negeri Melayu Bersekutu dalam temanya hanya berkisar soal kezaliman raja Melayu.

4. Dalam usaha menerangkan kejahatan pembsr Melayu menindas masyarakat sendiri mereka menggunakan teori barat (Marx-Kapitalis) untuk menerangkan keburukan sistem feudal Melayu. Masalahnya mana mugkin pengalaman masyarakat luar (Eropah) yang berbeza latarbelakang sejarah konstektualnya disamakan dengan realiti Alam Melayu.

Mereka membahagikan sejarah kepada dua jenis, sejarah tradisional dan moden. Kononnya, hanya selepas kuasa barat datang barulah elemen sejarah moden itu timbul yang dianggap sebagai sejarah yang bermanafaat untuk dikaji. Maklumat tempatan tidak diakui kerana penuh dengan elemen mitos, sebaliknya masyarakat Alam Melayu hanya patut bergantung kepada catatan orang barat tentang masyarakat Melayu untuk mengetahui makna sejarah sebenar. Atas dasar ini, mereka mengistiharkan sejarah negeri-negeri Melayu 
seperti Kelantan, Terengganu dan Pahang sebagai kabur dan tidak jelas. ${ }^{95}$ Lebih tepat lagi, mereka enggan mengakui sejarah tamadun Melayu Islam sebelum kedatangan kuasa kolonial. Akibatnya, sejarah tamadun Melayu tradisional dianggap tidak wujud, bahkan ditengelamkan sama sekali. Sebagai alternatifnya, andainya masyarakat Melayu ingin mengetahui sejarah mereka sendiri, mereka perlu merujuk kepada catatan sarjana kolonial. ${ }^{96}$

Catatan sejarah milik sarjana kolonial ini agak sempit yang hanya tertumpu di Negeri Melayu Bersekutu. Contohnya, sejarah negeri Melayu lain seperti Pahang dikatakan hanya bermula pada abad ke19. Ia hanya menumpukan kepada isu pergolakan politik yang penuh dengan keadaan huru hara yang memerlukan campurtangan British untuk melahirkan Law And Order di negeri terbabit. Hal ini memang diterangkan dalam catatan sarjana-pentadbir kolonial dan tali barutnya, Abdullah Munsyi. ${ }^{97}$ Lebih malang lagi, dalam kesemua catatan sejarah ini, masyarakat Melayu digambarkan sebagai masyarakat yang penuh elemen negatif dan penuh penindasan yang dilakukan oleh pembesar kepada masyarakat Melayu. ${ }^{98}$

Daripada kajian yang dilakukan oleh Husin Othman, terdapat sejumlah besar sarjana-pentadbir kolonial portugis, belanda dan British yang berusaha melakukan kajian tentang masyarakat Melayu. Dalam kesemua karya ini, tren utama yang dipakai adalah cuba memperlihatkan seolah-olah mereka yang menemui dan bertanggungjawab mentamadunkan Alam Melayu. ${ }^{99}$ Karya-karya sarjana-pentadbir kolonial ini walaupun berguna untuk dikaji, tetapi kesemuanya perlu dipandang secara kritikal kerana ianya mempergunakan beberapa paradigma kolonial yang sarat dengan kepentingan kolonial.

Di zaman selepas merdeka, ilmu kolonial telah mula dikritik hebat oleh sarjana tempatan. Berbanding dengan pendekatan keilmuaan era penjajah, kita dapat mengesan usaha sarjana tempatan melakukan rekonstruksi sejarah tempatan dari perspektif yang lebih holistik. Ianya membabitkan skop yang

95 W. A. Graham (1908), Kelantan : A State Of The Malay, Glasgow, h. 38; A. Rentse (1934), History Of Kelantan 1, JMBRAS, XII, pt. 2, 1934, h. 44.

96 Hanapi Dolah (1983), Struktur Dan Hubungan Masyarakat Melayu Tradisional Berdasarkan Sejarah Melayu : Satu Perbincangan Teoritis, SARI, v.1(2), h. 125-139

${ }^{97}$ Mohammad Saleeh Rahamad (2009), Pengaruh Barat Dalam Persuratan Awal Di Malaysia, Jurnal Pengajian Media Malaysia, v. 11, no.1, h. 113-132.

98 hanapi dolah, op.cit.

99 Hussain Othman (2011), Malay Muslim History As Seen By Western Colonialist, World Journal Of Islamic History And Civilization, v.1 (2), h. 117-129. 
agak luas merangkumi bidang perundangan Islam, perundangan, sastera, sains sosial, pentadbiran awam, ekonomi, pendidikan, pemikiran, pengurusan dan sebagainya. ${ }^{100}$

\section{Simpulan}

Sebagai rumusan akhir, terbukti kepada kita tentang keburukan yang ditinggalkan oleh ilmu kolonial membabitkan Islam di Malaysia. Dalam banyak hal, ia telah membantutkan proses pemerkasaan Islam di Malaysia. Jadi, hasil penganalisaan maqasid terhadap warisan ilmu kolonial membuktikan masih terlalu banyak usaha pemantapan Islam yang perlu dilakukan oleh sarjana Islam. Ia menuntut sarjana Islam meneruskan usaha jihad intelektual bagi menolak dan membetulkan nisbah negatif yang diletakkan pada Islam.

\section{Daftar Pustaka}

A.Arba'iyah Mohd Noor (2001), " Pensejarahan Di Dalam Tradisi Barat Dan Melayu : Satu Perbandingan Ringkas”, Dalam (Edit) Redzuan Othman, Jendela Masa, Kuala Lumpur : Penerbit UM.

Abd Moqsith Ghazali (2007), Mengubah Wajah Fiqh Islam, dalam Abd Hakim dan Yudi Latif (eds.), Bayang-Bayang Fanatisme: Esai-Esai Untuk. Mengenang Nurcholish Madjid, Jakarta: PSIK (Universitas Paramadina).

Abdul Rahman Abdullah (2000), Wacana Falsafah Sejarah : Perspektif Barat Dan Timur, Kuala Lumpur.

Abdul Rahman Abdullah (1994), Pengantar Ilmu Sejarah, Kuala Lumpur.

Abu Hassan Sham dan Mariyam Salim (1995), Sastera undang-undang, Kuala Lumpur.

Adian Husaini (2005), Wajah Peradaban Barat, Jakarta : Gema Insani.

Aliza Elias (2012), " Kecenderungan Paksi India : Implikasinya Terhadap Pensejarahan Islam Di Alam Melayu", Mohd Zaidi Ismal (Edit) Adab Dan Peradaban : Karya Pengi'tirafan Untuk. Syed Muhammad Naquib AlAttas, MPH publishing.

A.Wright dan T.H. Reid (1912), The Malay Peninsula, Londom, h. 315.

A.J. Stockwell (2009), The Crucible Of The Malayan Nation : The University And The Making Of A New Malaya. 1938-1962, Modern Asian Studies, v. 43.

100 Azmi Aziz (2011), Transisi Penting Sistem Berkerajaan Di Alam Melayu : Kes Malaysia, Akademika, 81 (2), h. 79-92. 
Anis Shakila Binti Ismail (2006), Pemikiran Islam Liberal Di Malaysia : Kajian Terbadap Isu Yang Ditimbulkan Oleh Farish Noor Dan Syed Akbbar Ali. Kertas projek Sarjana Muda Usuluddin .APIUM.

Azhar Ibrahim Alwee (2002), Orientalisme Dalam Pengajian Melayu, Dalam Persidangan Antarabangsa Babasa, Sastera Dan Kebangsaan Melayu Ke 2, Anjuran Jabatan Bahasa Dan Kebudayaan Melayu, Kumpulan Akademik Bahasa Dan Kebudayaan Asia, Institute Pendidikan Nasional, Pada 1-3hb September 2002.

Azmi Aziz (2011), Transisi Penting Sistem Berkerajaan Di Alam Melayu : Kes Malaysia, Akademika, 81 (2).

Barlow, H.S.(1995), Swettenham, Kuala Lumpur : Southdene Bhd.

Berthold Spuler (1960), The Muslim World: A Historical Survey, Leiden, part 1.

Bryan S. Turner (1964), "Gustave E. Von Grunebaum and the mimesis of Islam ", dalam Orientalism, Islam And Islamist.

Boxer, C.R. (1965), Some Portuguese Sources For Indonesian Historiography, Dalam Soedjatmoko (Eds), An Introduction To Indonesian Historiography, New Haven : Cornell University Press.

Daud Rasyid (2002), Pembaruan Islam Dan Orientalisme Dalam Sorotan, Jakarta : Media Akbar.

Edward W Said (1985), Orientalism, Middlesex: penguin Books.

Edward W. Said (1981), Covering Islam, How The Media And The Experts Determine Hows We See The Rest Of The World, London, h. 39-40, 60 dan 62.

E.E. Calverley (1958), Islam : An Introduction, The American University in Cairo Press.

E. G. De Eredia (1930), “ The description of Malaca ", dalam JMBRAS, v. 8:1.

Fawaz A. Gerges (1999), America And Political Islam; Clash Of Cultures Or Clash Of Interest, Cambridge : Cambridge University Press.

Friedrich Meinecke (1956), " Historicism And Its Problems “, Dalam The Varieties Of History, New York.

Fred R. Von Der Mehden (1993), Two Worlds Of Islam: Interaction Between Southeast Asia And The Middle East, Florida.

F. Swettenham (1893), About Perak, Singapore.

F. Swettenham(1955), British Malaya, London.

F. Swettenham (1895), Malay sketch, Singapore.

Hanapi Dolah (1983), Struktur Dan Hubungan Masyarakat Melayu Tradisional Berdasarkan Sejarah Melayu : Satu Perbincangan Teoritis, SARI, v.1(2). 
Hussain Othman (2008), Conceptual Understanding Of Myths And Legends In Malay History, $S A R I$, v. 26.

Hussain Othman (2011), Malay Muslim History As Seen By Western Colonialist, World Journal Of Islamic History And Civilization, v.1 (2).

Idris Zakaria (1999), " Intelek Eropah Dan Penentangan Terhadap Agama “, dalam Al-Maw'izah, bil. 7.

James E. Royster (1972), “ The Study Of Muhammad : A Survey Of Approaches From The Perspective Of The History And Phenomenology Of Religion “, Dalam The Muslim World, v. 62.

J.C. Leur (1955), Indonesian trade and society, The Hague, h. 169; K.P. Landon (1949), Southeast Asia: Crossroad of religions, Chicago.

Kees Groeneboer (1999), Politik Bahasa Kolonial Di Asia, Wacana, v. 1, no 2. Khasnor Johan (1983), “ Perkhidmatan Tadbir Melayu : Tradisi Dan Peranan Dalam Konteks Kerajaan Penjajah “, dalam Malaysia: Sejarah Dan Proses Pembangunan, Kuala Lumpur: Persatuan Sejarah Malaysia.

Kuntowijoyo (2004), Islam Sebagai Ilmu: Epistemology, Metodologi Dan Etika, Jakarta: Teraju Mizan.

Lukmanul Hakim Darusman (2008). Jihad In Two Faces Of Shariah: Sufism And Islamic Jurisprudence (Fiqh) And The Revival Of Islamic Movements In The Malay World. Tesis Ph.D yang tidak diterbitkan, The Australian National University.

Louay Safi (1998), Asas-Asas Ilmu Pengetahuan: Satu Kajian Perbandingan KaedahKaedah Penyelidikan Islam Dan Barat, terj. Nur Hadi Ihsan, Kuala lumpur. M.B. Hooker (1983), “ The Translation Of Islam Into South-East Asia “, dalam Islam In South-East Asia, Leiden.

Maryam Jameelah (1971), Islam And Orientalism, Lahore.

Mastuhu (1998), “Penelitian Agama Islam : Perspektif Antar Disiplin Ilmu : Tinjauan Disiplin Sosiologi ', Dalam Tradisi Baru Penelitian Agama Islam : Tinjauan Antar-Disiplin Ilmu, Bandung : Penerbit Nuansa.

Mohd FarhanAbd Rahman (2012), “ Pandangan Orientalis Terhadap Masyarakat Islam Di Tanah Melayu: Analisa Terhadap Karya Pilihan R.O. Winstedt", dalam Jumal Figh, 2012.

Mohd Zariat Abdul Rani (2005), Antara Islam Dan Hinduisme Di Alam Melayu : Beberapa Catatan Pengkaji Barat, SARI, v. 23.

Mohd Zariat Abdul Rani (2005), Antara Islam Dan Hinduisme Di Alam Melayu : Beberapa Catatan Pengkaji Barat, SARI, v. 23. 
Maurice Mandelbaum (1986), “ Historism “, dalam The Encyclopedia Of Philosophy, v. .

Mohd Azhar Abd Hamid (2001), Pengenalan Pemikiran Kritis Dan Kreatif, Skudai: Penerbit Universiti Teknologi Malaysia.

Mohd Hazim Shah Abdul Murad (2005), “ Epistemology Colonial : Satu Analisis Cirri Dan Kesannya ", Dalam (Edit) Mohamad Daud Mohamad, Pascakolonialisme Dalam Pemikiran Melayu, DBP : Kuala Lumpur.

Mohd Hazim Shah (2007), Historicizing Rationality : The Transmission Of Rationality And Science To The Malay States Under British Rule, dalam Asian Journal Of Social Science, 35.

Mohd Kamal Hassan (1996), “ Pembentukan Ilmu Kemasyarakatan Dari Perspektif Islam “, dalam Sains Sosial Dari Perspektif Islam, Kuala Lumpur: DBP.

Mohd Natsir Mahmud (1997), Orientalisme : Al-Quran Di Mata Barat ( Sebuah Studi Evaluatif), Semarang.

Mohamad Saleeh Rahamad (2007), Oksidentalisme Dalam Persuratan : Juzuk Penting Dalam Kajian Pascakolonial, Pemikir.

Mohammad Saleeh Rahamad (2009), Pengaruh Barat Dalam Persuratan Awal Di Malaysia, Jurnal Pengajian Media Malaysia, v. 11, no.1.

Mohammad Kamil Abdul Majid (2008), Pusat Kajian Orientalism: Analisis Terbadap Sikap Umat Islam, dibentang dalam International Seminar On Research In Islamic Studies, Anjuran APIUM pada 17-18 Disember 2008

Muhammad Ikhlas Rosele, Rahimin Affandi Abd Rahim \& Mohd Anuar Ramli (2015). Islamisasi Awal di Pahang: Satu Tinjauan Teori. Jurnal Kemanusiaan, 24(1).

Muhammad Syukri Salleh (2009), "Melayu-Islam Dan Sumber Kekuatan Yang Diabaikan", dalam Kalthum Ibrahim(ed.), Dunia Melayu Dan Islam : Satu Wacana. Bangi: Penerbit Universiti Kebangsaan Malaysia.

Norman Daniel (1966), Islam, Europe And Empire, Edinburgh.

Rahimin Affandi Abdul Rahim, Nor Adina Abdul Kadir ( 2012). Gerakan Feminisme Liberalism Di Malaysia : Analisis Kritikal, dalam prosiding World Congress On Islamic Systems 1- 5 December 2012. Kota Bharu, Kelantan.

Rahimin Affandi Abd Rahim (2010), "Pemodenan Dan Kesejahteraan Manusia Dari Perspektif Orientalism", dalam Seminar Serantau Islam dan 
Kesejabteraan Sejagat, Fakulti Usuluddin, UNISSA, Brunei, pada 24-25 Februari 2010

Rahimin Affandi Abdul Rahim (1999), Islamic legal reform in the administration of Islamic law in Malaysia: A critical analysis, tesis Ph.D untuk University of Birmingham.

Rahimin Affandi Abdul Rahim (1995), “Budaya Taqlid Di Dalam Masyarakat Melayn: Suatu Tinjauan Ringkas ", dalam Jurnal Syariah, v. 3, bil. 1.

Rahimin Affandi Abd Rahim (2007), "Etika Kepimpinan Islam Dan Isu Pembangunan Di Malaysia : Satu Analisis ", dalam Prosiding Seminar Kepimpinan Islam Peringkat Antarabangsa, anjuran APIUM, pada 1011 Julai 2007.

Rahimin Affandi Abd. Rahim (2005), "Citra Islam Dalam Pembentukan Manusia Melayu Moden Di Malaysia : Suatu Analisa", Jurnal Pengajian Melayu, v. 15.

R.O. Winstedt (1934), “ A History of Perak “, dalam JMBRAS, 12 (1).

R.W. Southern (1962), Western Viens Of Islam In The Middle Ages, Harvard.

Samuel Wee Tien Wang (1991), British Strategic Interests In The Straits Of Malacca 1786-1819, Tesis Sarjana Untuk Simon Fraser University.

Shaharuddin Maaruf (1993), Konsep Wira Dalam Masyarakat Melayu, Singapura : Pustaka Antara.

Shamsul Amri Baharuddin (2004), "Oksidentalisme: Pengertian Dan Hala Tuju”, Dalam Jurnal Pemikir.

Shamsul Amri Baharuddin (1983), " Perancangan Pembangunan Negara Selepas Merdeka 1957-1975 : Tinjauan Sejarah Perkembangan SosioEkonomi Malaysia", Dalam Malaysia : Sejarah Dan Proses Pembangunan, Kuala Lumpur.

Shukri Ahmad (1998), “ Agama Dan Masyarakat “, Dalam Pengenalan Kepada Sains Sosial, Kuala Lumpur.

Sivachandralingam Sundara Raja (2015), The Early British Administrators In The Malay States, 1874-1909, Jurnal Sejarah, v. 23, no 1.

Syamsuddin Arif (2008), Orientalis Dan Dianolisme Pemikiran, Jakarta : Gema Insan.

Syed Muhammad Dawilah al-Edrus (1999), Epistemologi Islam; Teori Ilmu Dalam Al-Quran, Kuala Lumpur.

Syed Muhammad Naquidd Al-Attas (1979), Aim And Objective of Islamic Education, Jeddah: University Of King, h.1; Abdul Aziz(2003), Islam And Secularism. Kuala Lumpur: ISTAC. 
Syed Muhammad Naquidd Al-Attas (1980), The Concept Of Education In Islam: A Framework For An Philosophy Of Education. Kuala Lumpur: Angkatan Belia Islam Malaysia.

Syed Muhammad Naquidd Al-Attas (2003), Islam And Secularism, hh. 162-163; Ismail Faruqi (1995), Islamization Of Knowledge, Herndon: IIIT.

Syed Muhd Khairudin Al-Junied (2003), From Noble Muslims To Saracen Enemies : Thomas Stamford Raffles's Discourse On Islam In The Malay World, SARI.

Sudibyo (2007), Kembali Ke Filologi : Filologi Indonesia Dan Tradisi Orientalisme, Humaniora, v. 19.

T.S. Raffles (1930), Memoir of the life and public services of Sir Stamford Raffles, London, v. 1.

Ummu Atiyah Ahmad Zakuan (2007), Hak Asasi Manusia Dan Demokrasi Dari Persepktif Islam Dan Barat, Dalam Mohd Izani Mohd Zain (ed.), Demokrasi Dan Dunia Islam : Perspektif Teori Dan Praktik, Kuala Lumpur : Penerbit UM.

Wang Gungwu (1970), Scholarship and the history and politics of Southeast Asia, Flinders University of South Australia.

W. A. Graham (1908), Kelantan: A State Of The Malay, Glasgow, h. 38; A. Rentse (1934), History Of Kelantan 1, JMBRAS, XII, pt. 2, 1934.

William J. Goode and Paul K. Hatt (1952), Methods In Social Research.

W. L. Richmond (1928), The Modern Malay, London.

W.M. Watt (1954_, "Economic And Social Aspects Of The Origin Of Islam “, dalam The Islamic Quarterly, v. 1, no. 1.

Zainal Abidin (2003), Sosiosophologi: Sosiologi Islam Berbasis Hikmah. Bandung: Penerbit Pustaka Setia.

Zainal Kling (1994), Antropologi tafsiran : sumbangan kebudayaan Melayu kepada teori, Syarahan perdana untuk pengukuhan profesor, Kuala Lumpur.

Zawiah Yahya (1994), Resisting Colonialist Discourse, Penerbit UKM. 